\title{
Leptin and metabolic hormones in preterm newborns
}

\author{
P C Ng, C W K Lam, C H Lee, G W K Wong, T F Fok, I H S Chan, K C Ma, E Wong
}

\begin{abstract}
Aim-To investigate the inter-relation between leptin and other metabolic hormones in preterm and term infants and to explore whether a functional "adipoinsular axis" might exist in preterm newborns. Methods-A total of 140 preterm and term newborns were prospectively recruited and categorised according to gestation length. Blood samples were taken at 24 hours (day 1), and on day 4-5 of life.

Results-Serum leptin, cortisol, free thyroxine, and plasma ACTH on day 1 were significantly higher in term than in preterm infants. The relation between serum leptin and gestation followed a non-linear pattern; the slope of the curve began to increase steeply between 33 and 35 weeks gestation. Serum leptin on day 1 was significantly associated with serum insulin, insulin:glucose ratio, and plasma ACTH in infants less than 34 weeks gestation; serum leptin on day 1 and day 4-5 were significantly correlated with insulin:glucose ratio in infants 34 or more weeks gestation. Significant changes in the pattern of metabolic hormones were observed in the first week of life. Serum insulin and plasma glucose were significantly increased between day 1 and day 4-5; serum leptin was significantly decreased.
\end{abstract}

Conclusions-The circulating leptin concentration increases markedly after 34 weeks gestation and bears a close temporal relation with the exponential accumulation of body fat mass during that period. The inter-relation between serum leptin and insulin or insulin:glucose ratio before and after 34 weeks gestation indicates that the "adipoinsular axis" is likely to be functional in early (<34 weeks gestation) intrauterine life. The rapid decline in the circulating concentrations of leptin after birth may be of physiological advantage to preterm and term newborns by limiting their body energy expenditure and conserving nutritional reverses for subsequent growth and development.

(Arch Dis Child Fetal Neonatal Ed 2000;83:F198-F202)

Keywords: leptin; adipoinsular axis

Leptin, a newly discovered adipostatic hormone, has been found to play an important role in the regulation of body lipid metabolism, feeding behaviour, and energy homoeostasis. ${ }^{1-4}$ Recent evidence suggests that circulating leptin in children and adults can be influenced by metabolic hormones such as corticosteroids and insulin, ${ }^{5-7}$ systemic infection, ${ }^{8}$ and different stages of physical and pubertal development. ${ }^{9}{ }^{10}$ Yet little is known concerning the role of leptin in fetal development and the control of body composition in preterm and term infants. Glucose is the principal source of energy for the human fetus but there is an abrupt change in nutrient supply immediately after birth with lipid contributing more than $60 \%$ of the total body energy expenditure. ${ }^{11}$ Failure to increase the adipose tissue mass during gestation causes increased neonatal morbidity. ${ }^{12}{ }^{13}$ As fetal growth does not follow a linear pattern throughout the course of pregnancy and fat is predominantly accreted in the last trimester of gestation, ${ }^{14}$ the understanding of the interaction of leptin with other metabolic hormones in preterm and term infants may provide valuable insights into this important physiological phenomenon. Our recent study on leptin and metabolic hormones in normal term infants and infants of diabetic mothers suggests that a functional "adipoinsular axis" might exist in term newborns. ${ }^{15}$ Whether the axis is active in preterm infants remains to be determined.

This study was undertaken to investigate the inter-relation between leptin and other metabolic hormones including insulin, corticotropin (ACTH), cortisol, thyroid stimulating hormone (TSH), and free thyroxine (FT4) in preterm (less than 37 weeks gestation) and term (37 weeks or more gestation) infants. The change in the pattern of leptin and other metabolic hormones in the first few days life was also determined. The results may provide important information about the ontogeny of leptin in human infants and the understanding of leptin and other metabolic hormones in the regulation of the fetal body weight and composition.

\section{Patients and methods}

\section{STUDY POPULATION}

A total of 140 newborn infants admitted to the neonatal unit were prospectively recruited between March 1998 and May 1999. Enrolled term (gestational age 37 weeks or more, $\mathrm{n}=43$ ) and near term infants (gestational age between 32 and 36 weeks, $n=54$ ) were newborns with increased risk of perinatal infection, but were subsequently proven to be non-infected. Preterm infants with gestational age less than 32 weeks $(n=43)$ or birth weight below $2300 \mathrm{~g}$ were routinely admitted to the neonatal unit for clinical assessment and monitoring. Gestational age was assessed by the mother's last menstrual period, early ultrasound dating, and the new Ballard Score 
Table 1 The clinical characteristics of preterm and term infants

\begin{tabular}{|c|c|c|c|c|}
\hline & Group $1(n=43)$ & Group $2(n=54)$ & Group $3(n=43)$ & Comparison between the three groups \\
\hline Gestation (weeks) ${ }^{\star}$ & $29.6(28.0-30.4)$ & $34.2(33.3-35.3)$ & $40.0(38.7-40.6)$ & Group $3>$ group $2>$ group 1 \\
\hline Birth weight $(\mathrm{g})^{\star}$ & $1180(970-1410)$ & $1973(1700-2110)$ & $3300(2900-3970)$ & Group $3>$ group $2>$ group 1 \\
\hline Length $(\mathrm{cm})^{\star}$ & $37.3(35.5-40.2)$ & $43.6(42.1-44.6)$ & $49.9(47.8-52.1)$ & Group $3>$ group $2>$ group 1 \\
\hline $\mathrm{BMI}\left(\mathrm{kg} / \mathrm{m}^{2}\right)^{\star}$ & $8.2(7.6-9.4)$ & $10.3(9.5-11.0)$ & $13.8(12.8-15.2)$ & Group $3>$ group $2>$ group 1 \\
\hline Placental weight $(\mathrm{g})^{\star}$ & $305(300-400)$ & $415(350-495)$ & $550(500-600)$ & Group $3>$ group $2>$ group 1 \\
\hline Male/female (n) & $27: 16$ & $25: 29$ & 23: 20 & - \\
\hline $\begin{array}{l}\text { Mode of delivery (n) })^{\star \star \star} \text { (normal : caesarean } \\
\text { section : forceps or ventouse) }\end{array}$ & $16: 26: 1$ & $25: 28: 1$ & $21: 13: 9$ & - \\
\hline Maternal smoker (n) & 1 & 3 & 1 & - \\
\hline Rupture of membrane $>24 \mathrm{~h}(\mathrm{n})$ & 10 & 12 & 7 & - \\
\hline Maternal pre-eclampsia (n) & 9 & 9 & 0 & - \\
\hline Antenatal dexamethasone (doses) & $2(2-4)$ & $2(0-4)$ & - & - \\
\hline $\begin{array}{l}\text { Time between last dose of dexamethasone and } \\
\text { delivery }(\mathrm{h})\end{array}$ & $40(17-75)$ & $68(7-141)$ & - & - \\
\hline \multicolumn{5}{|l|}{ Apgar scores $\star$} \\
\hline at $1 \mathrm{~min}$ & $6(5-8)$ & $8(7-9)$ & $9(8-9)$ & Groups 2 and $3>$ group 1 \\
\hline at $5 \mathrm{~min}$ & $9(8-9)$ & $10(9-10)$ & $10(9-10)$ & Groups 2 and $3>$ group 1 \\
\hline \multicolumn{5}{|l|}{ Arterial cord blood } \\
\hline $\mathrm{pH}$ & $7.29(7.22$ to 7.32$)$ & $7.29(7.24$ to 7.33$)$ & $7.27(7.23$ to 7.30$)$ & - \\
\hline Base excess & $-5.9(-8.7$ to -3.9$)$ & $-5.9(-7.2$ to -3.9$)$ & $-6.5(-7.8$ to -3.8$)$ & - \\
\hline \multicolumn{5}{|l|}{ Mechanical ventilation $(n)^{\star}$} \\
\hline on day 1 & 38 & 9 & 0 & - \\
\hline on day $4-5$ & 26 & 3 & 0 & - \\
\hline \multicolumn{5}{|l|}{ Oxygen requirement $\left(\mathrm{FiO}_{2}\right)^{\star}$} \\
\hline on day 1 & $0.23(0.21-0.30)$ & $0.21(0.21-0.21)$ & $0.21(0.21-0.21)$ & - \\
\hline on day $4-5$ & $0.21(0.21-0.23)$ & $0.21(0.21-0.21)$ & $0.21(0.21-0.21)$ & - \\
\hline
\end{tabular}

Results expressed as median (interquartile range). ${ }^{\star} \mathrm{p}<0.05,{ }^{\star \star \star} \mathrm{p}<0.001$; ( $>$ significantly greater).

examination. ${ }^{16}$ Exclusion criteria were similar to those of our previous study. ${ }^{15}$

FEEDING REGIME

Infants less than 32 weeks gestation were routinely commenced on intravenous dextrose after birth to prevent hypoglycaemia. Very low birth weight infants had enteral feeding introduced between day 5 and 7 of life and the quantity of milk was cautiously stepped up by 0.5-1 $\mathrm{ml} /$ hour/day, depending on tolerance. Near term infants had enteral feeding started earlier between day 1 and 5 of life; the rate of milk increment varied between 2 and 10 $\mathrm{ml} /$ feed/day, depending on gestation. Term infants were usually commenced on full enteral feeding soon after delivery.

BLOOD SAMPLES AND HORMONAL ASSAYS

The first blood samples were collected when the infants were about 24 hours of age (day 1), and a second sample was obtained on day 4-5 of life. Details of specimen collection, transportation, processing, storage, and methods of hormonal assay have been described previously. ${ }^{15}$

DATA COLLECTION AND STATISTICAL ANALYSIS Demographic and clinical data were prospectively collected (see table 1). Ethical approval of the study was granted by the Clinical Research Ethical Committee of the Chinese University of Hong Kong, and informed parental consent was obtained before commencement of the test. The statistical tests and computer software used in this study were similar to those described in our previous study. ${ }^{15}$ In addition, the Wilcoxon rank sum test was used to compare serum leptin and serum/plasma concentrations of other metabolic hormones between day 1 and day 4-5. Statistically significant or near significant $(\mathrm{p}<0.15)$ parameters associated with leptin were further subjected to the generalised additive models for multivariate analysis,${ }^{17}$ using the S-Plus statistical program (version 4.3, MathSoft Inc., Seattle, Washington). This nonparametric mathematical technique enables us to develop models which more accurately represent the relation between multivariate predictor variables and the outcome variable.

\section{Results}

SUBGROUP ANALYSIS

Groups 1 (preterm), 2 (near term), and 3 (term) represented infants who were less than $32,32-36$, and 37 or more weeks gestation, respectively. Table 1 summarises the clinical characteristics of these infants. Gestational age, birth weight, body length, body mass index (BMI), and placental weight were significantly higher in older gestation infants, whereas Apgar scores at 1 and 5 minutes were significantly lower in preterm infants. In addition, significantly more preterm infants were born by caesarean section and required

Table 2 Blood hormone and plasma glucose concentrations on day 1 of life

\begin{tabular}{|c|c|c|c|c|}
\hline & Group $1(n=43)$ & Group $2(n=54)$ & Group $3(n=43)$ & Comparison between the three groups \\
\hline Leptin $(\mathrm{ng} / \mathrm{ml})^{\star}$ & $0.05(0.05-0.25)$ & $0.23(0.07-0.46)$ & $1.7(0.48-6.33)$ & Group $3>$ groups 1 and 2 \\
\hline $\mathrm{ACTH}(\mathrm{pmol} / 1)^{\star}$ & $3.3(2.7-3.9)$ & $5.4(3.9-9.5)$ & $7.8(4.9-18.3)$ & Group $3>$ group 1 ; group $2>$ group 1 \\
\hline Cortisol $(\mathrm{nmol} / \mathrm{l}) \dagger$ & $145(89-311)$ & $228(142-354)$ & $298(205-415)$ & Group $3>$ group 1 \\
\hline Insulin $(\mathrm{pmol} / \mathrm{ml})$ & $30.1(13.9-52.4)$ & $27.7(12.9-51.7)$ & $23.0(7.2-53.1)$ & - \\
\hline Glucose $(\mathrm{mmol} / \mathrm{l}) \dagger$ & $5.3(3.8-7.4)$ & $4.5(4.1-5.4)$ & $4.1(3.7-4.7)$ & Group $1>\operatorname{group} 3$ \\
\hline Insulin:glucose ratio & $4.7(2.6-9.2)$ & $6.0(2.8-10.6)$ & $5.5(2.2-10.8)$ & - \\
\hline $\mathrm{FT} 4(\mathrm{pmol} / \mathrm{l})^{\star}$ & $10.9(6.7-15.6)$ & $22.5(16.7-27.9)$ & $28.6(23.7-33.3)$ & Group $3>$ group $2>$ group 1 \\
\hline Cord TSH $(\mathrm{mIU} / \mathrm{l})$ & $5.2(3.0-8.2)$ & $6.4(4.8-7.6)$ & $4.9(3.9-7.2)$ & - \\
\hline
\end{tabular}

Results expressed as median (interquartile range); ${ }^{\star} \mathrm{p}<0.05, \mathrm{tp}<0.005$; ( $>$ significantly greater). 
Table 3 Blood hormone and plasma glucose concentration on day 4-5 of life

\begin{tabular}{lllll}
\hline & Group 1 $(n=43)$ & Group 2 $(n=54)$ & Group 3 $(n=43)$ & Comparison between the three groups \\
\hline Leptin $(\mathrm{ng} / \mathrm{ml})^{\star}$ & $0.11(0.05-0.24)$ & $0.13(0.05-0.35)$ & $0.77(0.25-2.33)$ & Group 3 > groups 1 and 2 \\
ACTH $(\mathrm{pmol} / \mathrm{l})$ & $3.9(3.2-6.5)$ & $5.4(3.2-8.1)$ & $6.1(4.0-9.4)$ & - \\
Cortisol $(\mathrm{nmol} / 1 /)^{\star}$ & $201(99-322)$ & $243(152-349)$ & $134(90-260)$ & Group 2 > group 3 \\
Insulin $(\mathrm{pmol} / \mathrm{ml})$ & $42.4(15.1-73.9)$ & $35.6(19.9-56.0)$ & $49.5(26.5-92.6)$ & - \\
Glucose $(\mathrm{mmol} / 1)^{\star \star \star}$ & $6.1(5.1-7.2)$ & $5.2(4.4-6.1)$ & $4.9(4.3-5.4)$ & Group 1 > groups 2 and 3 \\
Insulin:glucose ratio & $6.1(3.3-11.6)$ & $7.2(4.9-11.0)$ & $10.4(5.6-18.3)$ & - \\
FT4 $(\mathrm{pmol} / 1)^{\star}$ & $11.5(6.6-16.7)$ & $18.6(15.7-22.2)$ & $24.0(18.9-27.3)$ & Group 3 > group 2 > group 1 \\
\hline
\end{tabular}

Results expressed as median (interquartile range); ${ }^{\star} \mathrm{p}<0.05,{ }^{\star \star \star} \mathrm{p} p 0.001$; ( $>$ significantly greater).

mechanical ventilation or oxygen supplementation on day 1 and day 4-5.

Table 2 summarises the blood hormone and plasma glucose concentrations on day 1 . Serum leptin, cortisol, FT4, and plasma ACTH were significantly higher in older gestation infants, whereas plasma glucose was significantly lower in group 3 than in group 1.

Table 3 summarises the blood hormone and plasma glucose concentrations on day 4-5. Serum leptin and FT4 remained significantly

Table 4 Significant correlations between serum leptin and other metabolic hormones before and after 34 weeks of gestation

\begin{tabular}{|c|c|c|c|c|}
\hline & \multicolumn{2}{|c|}{$<34$ weeks gestation $(n=65)$} & \multicolumn{2}{|c|}{$\geqslant 34$ weeks gestation $(n=75)$} \\
\hline & Correlation $(r)$ & p value & Correlation (r) & $p$ value \\
\hline \multicolumn{5}{|l|}{ Day 1} \\
\hline \multicolumn{5}{|l|}{ Leptin } \\
\hline Insulin & 0.28 & $<0.05$ & - & - \\
\hline Insulin:glucose ratio & 0.32 & $<0.05$ & 0.24 & $<0.05$ \\
\hline ACTH & 0.26 & $<0.05$ & - & - \\
\hline \multicolumn{5}{|l|}{ Insulin } \\
\hline Leptin & 0.28 & $<0.05$ & - & - \\
\hline Insulin:glucose ratio & 0.94 & $<0.001$ & 0.96 & $<0.001$ \\
\hline Glucose & - & - & 0.36 & $<0.005$ \\
\hline FT4 & - & - & -0.26 & $<0.05$ \\
\hline \multicolumn{5}{|l|}{ ACTH } \\
\hline Leptin & 0.26 & $<0.05$ & - & - \\
\hline Cortisol & - & - & 0.55 & $<0.001$ \\
\hline \multicolumn{5}{|l|}{ FT4 } \\
\hline Insulin & - & - & -0.26 & $<0.05$ \\
\hline Insulin:glucose ratio & - & - & -0.23 & $<0.05$ \\
\hline \multicolumn{5}{|l|}{ Day 4-5 } \\
\hline \multicolumn{5}{|l|}{ Leptin } \\
\hline Insulin:glucose ratio & - & - & 0.27 & $<0.05$ \\
\hline \multicolumn{5}{|l|}{ Insulin } \\
\hline Insulin:glucose ratio & 0.89 & $<0.001$ & 0.94 & $<0.001$ \\
\hline \multicolumn{5}{|l|}{ ACTH } \\
\hline Cortisol & - & - & 0.55 & $<0.001$ \\
\hline
\end{tabular}

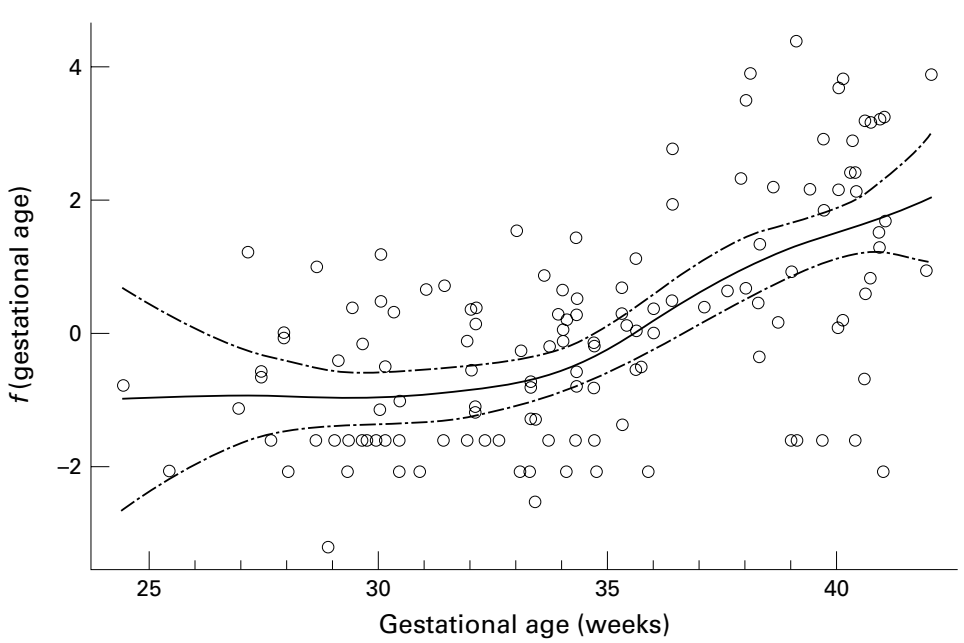

Figure 1 The non-linear relation between serum leptin on day 1 and gestational age, after adjustment for sex. Serum leptin is expressed as a fitted function for gestational age. The dotted lines represent twice the pointwise asymptotic standard errors of the estimated curve. The points are partial residuals (the fitted values for each function plus the overall residuals from the generalised additive model). higher in older gestation infants, whereas plasma glucose was significantly lower in groups 2 and 3 than in group 1 . Serum cortisol was significantly higher in group 2 than in group 3 on day $4-5$.

OVERALL ANALYSIS

When the results were pooled and analysed, serum leptin on day 1 was significantly correlated with gestation, birth weight, body length, BMI, and placental weight $(\mathrm{p}<0.001$, $r>0.36)$. However, when these parameters were subjected to the generalised additive models for multivariate analysis, only female sex and gestation $(p<0.01)$, birth weight $(\mathrm{p}<0.001)$, or BMI $(\mathrm{p}<0.02)$ were found to be significantly associated with serum leptin. Plasma ACTH, serum cortisol, and FT4 on day 1 were also significantly correlated with gestation ( $\mathrm{p}<0.01, r>0.25)$, placental weight $(\mathrm{p}<0.01, r>0.24)$ and the aforementioned anthropometric parameters $\quad(\mathrm{p}<0.05$, $r>0.20$ ). In addition, serum cortisol on day 1 was significantly higher in infants born by normal or instrumental delivery than by caesarean section $(p<0.05)$, and in those whose mother had rupture of membranes longer than 24 hours $(\mathrm{p}<0.05)$.

Similarly, gestation, birth weight, body length, BMI, and placental weight on day 4-5 were significantly correlated with serum leptin $(\mathrm{p}<0.001, r>0.41)$ and FT4 $(\mathrm{p}<0.001, r>$ 0.41 ). When these parameters were subjected to the generalised additive models for multivariate analysis, only female sex and gestation $(\mathrm{p}<0.005)$, birth weight $(\mathrm{p}<0.02)$, or BMI $(\mathrm{p}<0.002)$ were significantly associated with serum leptin. Both plasma ACTH and serum cortisol on day 4-5 were significantly higher in infants whose mother had rupture of membranes longer than 24 hours $(p<0.05$ and $\mathrm{p}<0.01$, respectively).

As the relation between serum leptin and gestation followed a non-linear pattern (fig 1) and the slope of the curve began to increase steeply between 33 and 35 weeks gestation, we assessed the inter-relation between serum leptin and other metabolic hormones before and after 34 weeks gestation. Serum leptin on day 1 was significantly associated with serum insulin, insulin:glucose ratio, and plasma ACTH in infants less than 34 weeks gestation, whereas serum leptin on day 1 and day $4-5$ was significantly correlated with insulin:glucose ratio in infants 34 or more weeks gestation (table 4). Similarly, serum leptin and BMI showed a non-linear relation (fig 2). 


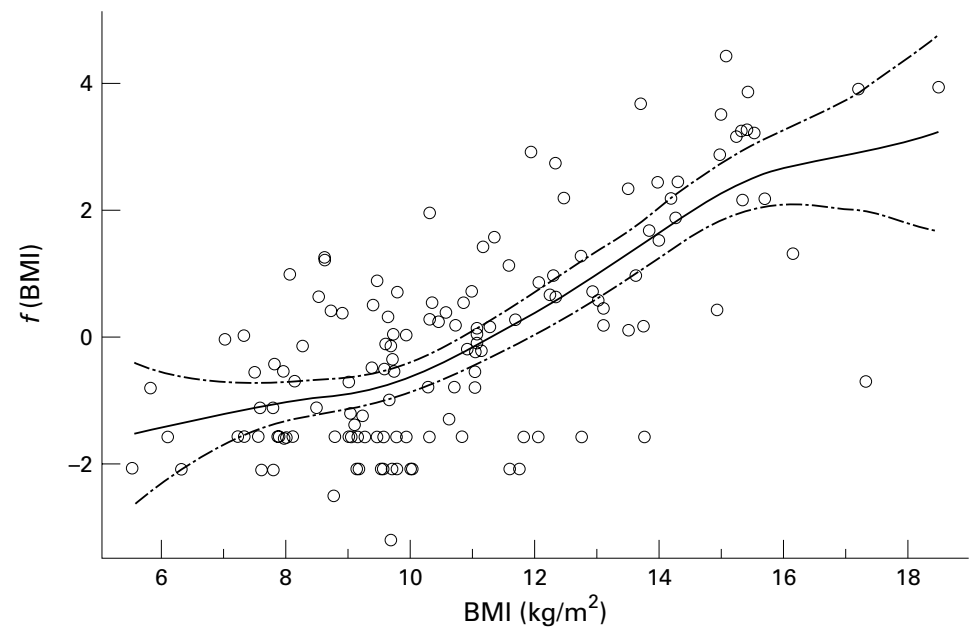

Figure 2 The non-linear relation between serum leptin on day 1 and BMI, after adjustment for sex. Serum leptin is expressed as a fitted function for BMI. The dotted lines represent twice the pointwise asymptotic standard errors of the estimated curve. The points are partial residuals (the fitted values for each function plus the overall residuals from the generalised additive model).

\section{Key message}

Serum leptin increases considerably after 34 weeks gestation and bears a close temporal relation with the rapid accumulation of body fat mass during late gestation. The association between serum leptin and insulin or insulin:glucose ratio suggests that the "adipoinsular axis" is likely to be functional in early (less than 34 weeks gestation) intrauterine life

adipoinsular axis becomes fully matured, recent studies reported the presence of leptin in fetal cord blood as early as $18-26$ weeks gestation. ${ }^{9} 181922$ Thus, in view of the dramatic increase in serum leptin after 34 weeks gestation and the rapid accumulation of fetal fat mass during this period, we postulate that the adipoinsular axis is likely to be active and functional before 34 weeks gestation.

Like leptin, other metabolic hormones including ACTH, cortisol, and FT4 are also positively correlated with gestation, birth weight, and BMI. The pattern indicates that these endocrine axes are also maturating and become increasingly active with advancing gestations. Similar to our previous study, ${ }^{15}$ a significant association between serum leptin and hormones of the hypothalamic-pituitaryadrenal (HPA) axis is observed (table 4). As corticosteroids have the ability to increase leptin production, ${ }^{5619}$ and insulin has also been shown in vitro to block corticosteroid stimulated release of leptin, ${ }^{7}$ it is possible that hormones of the HPA and adipoinsular axes may be inter-related with each other. We speculate that this may be one of the mechanisms in which the level of stress may influence body energy homoeostasis and consequently affects the body weight and fat regulation. An anticipated association between serum leptin and plasma ACTH in infants beyond 34 weeks gestation was not found. Whether the use of antenatal dexamethasone in preterm infants influences the relation between the two axes requires further investigation. Moreover, our results confirm the observations that higher plasma ACTH or serum cortisol concentrations are found in infants born by normal or instrumental delivery than by caesarean section, in infants whose mothers had prolonged rupture of membranes, and in those who suffered from perinatal stress with suboptimal Apgar scores or adverse arterial cord blood parameters (data not shown). ${ }^{23-25}$ Nonetheless, in contrast to other metabolic hormones, serum cortisol concentrations on day 4-5 in preterm infants (groups 1 and 2) are higher than those of older gestation infants (group 3). This finding can be explained by the fact that many preterm infants are still under severe stress, requiring mechanical ventilation and intensive care treatment at this stage. Hence, they have higher circulating concentrations of stress hormones. ${ }^{23}$

The hormonal patterns of leptin, insulin, and FT4 show significant changes between day 1 
and day 4-5. ACTH and cortisol reveal a sharp decline in blood concentration in the term newborns (group 3), but their overall concentrations between day 1 and day 4-5 are unaffected. It is likely that the hormonal concentrations are influenced by the degree of stress experienced by preterm infants. ${ }^{23}$ Insulin, an anabolic hormone, shows an increase in serum concentration after birth, whereas leptin and FT4 show a rapid decline in their circulating concentrations. Ong and Matsuda and their coworkers suggested that cord serum leptin concentrations correlated inversely with postnatal weight gain. ${ }^{22}{ }^{26}$ Low circulating concentrations of leptin and FT4 may, therefore, be a physiological advantage to newborn infants as body energy expenditure can be minimised and nutritional reserves conserved for subsequent growth and development. ${ }^{9}$ Thus, it is possible that the fetal adipoinsular axis and the concentration of serum leptin at birth may influence the "programming" of satiety and body metabolism, thereby determining postnatal weight gain and adiposity. ${ }^{26}$

Our results, as in previous studies, ${ }^{182126}$ reveal a sex difference with higher serum leptin in female than in male infants. This difference in serum leptin is most apparent after 34 weeks gestation when the rate of intrauterine fat deposition is at its peak. ${ }^{18}$ Whether this phenomenon of sexual dimorphism represents a sex difference in body fat distribution or is a result of the gonadal steroid status in utero remains to be determined.

In summary, we have shown that circulating leptin concentration increases considerably after 34 weeks gestation and coincides with the rapid accumulation of adipose tissue during late gestations. The association between serum leptin and insulin or insulin:glucose ratio before and after 34 weeks gestation further illustrates that the "adipoinsular axis" is likely to be active in early (less than 34 weeks gestation) intrauterine life. The results in this and in our previous study ${ }^{15}$ both show a significant association between leptin and hormones of the HPA axis, and suggest that there may be an important link between the human stress response and body weight or fat regulation. Again, female infants have significantly higher circulating leptin concentrations than male infants. A rapid decline in the circulating concentrations of leptin and FT4 after birth may be of physiological advantage to newborn infants by limiting body energy expenditure and conserving nutritional reserves for growth and development.

1 Zhang Y, Proenca R, Maffei M, Barone M, Leopold L, Friedman JM. Positional cloning of the mouse obese gene and its human homologue. Nature 1994;372:425-32.
2 Campfield LA, Smith FJ, Guisez Y, Devos R, Burn P. Recombinant mouse $O B$ protein: evidence for a peripheral Recombinant mouse $O B$ protein: evidence for a peripheral signal linking adipos

3 Considine RV, Sinha MK, Heiman ML, et al. The protein product of $o b$ gene is elevated in human obesity: effect of weight loss, fasting and feeding. $N$ Engl $f \mathrm{Med}$ 1996;334:292-5.

4 Salbe AD, Nicolson M, Ravussin E. Total energy expenditure and the level of physical activity correlate with plasma leptin concentrations in five-year-old children. 7 Clin Invest 1997;99:592-5.

5 Miell SP, Englaro P, Blum WT. Dexamethasone induces an acute and sustained rise in circulating leptin levels in normal human subjects. Horm Metab Res 1996;28:704-7.

6 Larsson H, Ahren B. Short-term dexamethasone treatment increases plasma leptin independently of changes in insulin sensitivity in healthy women. $f$ Clin Endocrinol Metab 1996;81:4428-32.

7 Considin RV, Nyce MR, Kolaczynski JW, et al. Dexamethasone stimulates leptin release from human adipocytes: unexpected inhibition by insulin. $f$ Cell Biochem 1997;64:254-8

8 Bornstein SR, Licinio J, Tauchnitz R, et al. Plasma leptin levels are increased in survivors of acute sepsis: associated loss of diurnal rhythm in cortisol and leptin secretion. 7 Clin Endocrinol Metab 1998;83:280-3.

9 Harigaya A, Nagashima K, Nako Y, Morikawa A. Relationship between concentration of serum leptin and fetal

10 Ahmed ML, Ong KK, Morrell DJ, et al. Longitudinal study of leptin concentrations during puberty: sex differences
and relationship to changes in body composition. $\mathscr{f}$ Clin Endocrinol Metab 1999;84:899-905.

11 Putet G. Lipids as an energy source for the premature and full-term neonate. In: Polin RA, Fox WW, eds. Fetal and neonatal physiology, 2nd edn. Philadelphia: WB Saunders, 1998:489-93.

12 Campbell S, Soothill P. Detection and management of intrauterine growth retardation: a British approach. In: Chervenak FA, Isaacson GC, Campbell S, eds. Ultrasound in obstetrics and gynecology, vol 2. Boston: Little Brown, 1993:1432-5

13 Harding JE, Charlton V. Experimental nutritional supplementation for intrauterine growth retardation. In: Harrison M, Golbus MS, Filly RA, eds. The unborn patient. Philadelphia: WB Saunders, 1991:598-609.

14 Widdowson EM, Southgate DAT, Hey EN. Nutrition and metabolism of the fetus and infant. In: Visser HKA, ed. The Hague: Martinus Nijhoff 1979;169-177.

$15 \mathrm{Ng}$ PC, Lam CWK, Lee CH, et al. Leptin and metabolic hormones in infants of diabetic mothers. Arch Dis Child Fetal Neonatal Ed 2000;83:193-7.

16 Ballard JL, Khoury JC, Wedig K, Wang L, Eiler-Walsman BL, Lipp R. New Ballard Score, expanded to include extremely premature infants. F Pediatr 1991;119:417-23.

17 Hastie T, Tibshirani R. Generalized additive models for medical research. Stat Method Med Res 1995;4:187-96.

18 Jaquet D, Leger J, Levy-Marchal C, Oury JF, Czernichow P. Ontogeny of leptin in human fetuses and newborns: effect of intrauterine growth retardation on serum leptin

19 Shekhawat PS, Garland JS, Shivpuri C, et al. Neonatal cord blood leptin: its relationship to birth weight, body mass index, maternal diabetes, and steroid. Pediatr Res 1998;43:338-43.

20 Marchini G, Fried G, Östlund E, Hargenäs L. Plasma leptin in infants: relation to birth weight and weight loss. Pediatrics 1998;101:429-32.

21 Hassink SG, de Lancey E, Sheslow DV, et al. Placental leptin: an important new growth factor in intrauterine and neonatal development? Pediatrics 1997;100 http:/ www.pediatrics.org/cgi/content/full/100/1/el

22 Matsuda J, Yokota I, Iida $M$, et al. Dynamic changes in serum leptin concentrations during the fetal and neonatal serum leptin concentrations during

$23 \mathrm{Ng}$ PC, Wong GWK, Lam CWK, et al. The pituitaryadrenal response in preterm very low birth weight infants after treatment with antenatal corticosteroids. $\mathcal{F}$ Clin Endocrinol Metab 1997;82:3548-52.

24 Lao TT, Panesar. The effect of labour on prolactin and cortisol concentrations in the mother and the fetus. Eur $\mathcal{F}$ Obstet Gynecol Reprod Biol 1989;30:233-8.

25 Gasparoni A, Chirico G, De Amici D, et al. Neutrophil chemotaxis in infants delivered by caesarean section. Eur $\mathcal{F}$ Pediatr 1991;150:481-2.

26 Ong KKL, Ahmed ML, Sherriff A, et al. Cord blood leptin is associated with size at birth and predicts infancy weight gains in humans. F Clin Endocrinol Metab 1999;84:1145-8. 